\title{
COMPUTER-AIDED PROTOTYPING OF INTERDIGITAL TRANSDUCERS FOR THE STRUCTURAL HEALTH MONITORING OF PLANAR STRUCTURES
}

\begin{abstract}
SUMMARY
In recent years an intensive research activity into the application of guided waves (GWs) for structural health monitoring (SHM) can be observed. For instance, Lamb waves (LWs) have shown a great potential in monitoring of thin, planar structures. However, due to the dispersive and multimodal nature of the LWs, their snapshots can consist of many pulses even for an intact structure, which makes damage detection very complex. Moreover, small PZT transducers, most commonly used in SHM systems, act normally as omni-directional wave sources; therefore, dense or sparse transducers networks are required for damage localization. Some of the above-mentioned drawbacks of single PZT emitters and sensors can be overcome using interdigital transducers (IDT) designed to excite and sense a single, selected mode. The mode-tuning is performed by changing the span of finger electrodes to match the wavelength of the excited mode for the selected frequency. An IDT is a directional source, therefore, it generates a wave steered to the direction perpendicular to the electrodes. The width of the excited main lobe can be determined by the length of the electrodes. Since many parameters of the IDTs influence the LWs propagation, techniques for the simulation of the wave excitation and propagation are needed. In the paper, numerical tools for the computer aided design and virtual prototyping of the IDTs are presented. The simulation technique is based on the frequency-dependent transfer function of the structure, and due to its computational efficiency it can be used for fast testing of IDTs' performance and for preliminary transducer design for further finite element simulations, and prototyping.
\end{abstract}

Keywords: Lamb wave, ultrasonic, numerical simulation, damage detection, Structural Health Monitoring, SHM

\section{STRESZCZENIE}

W ostatnich latach obserwowany jest gwattowny rozwój technik monitorowania stanu konstrukcji (ang. SHM) opartych na metodach ultradźwiękowych. Jednym z typów fal, szczególnie przydatnych do monitorowania konstrukcji ptytowych, sa fale Lamba. Jednakże ich dyspersyjny $i$ wielopostaciowy charakter powoduje, że proces detekcji uszkodzeń z ich zastosowaniem wymaga zastosowania zawansowanego przetwarzania sygnatów. Ponadto, typowe przetworniki PZT, generuja fale wielokierunkowa, co powoduje potrzebę stosowania wielu przetworników w celu lokalizacji uszkodzenia. Przetworniki międzypalczaste (ang. IDT) sa wolne od niektórych, wspomnianych powyżej, wad przetworników PZT, gdyż sa one projektowane do wzbudzania i wykrywania wybranych postaci drgań. Dostrajanie przetwornika do danej postaci drgań odbywa się przez zmianę rozstawu elektrod palczastych tak, aby odległość pomiędzy elektrodami podłączonymi do tej samej fazy odpowiadała dtugości fali w wybranej częstotliwości. Przetworniki IDT sa źródłami kierunkowymi, fala jest generowana w kierunku prostopadtym do elektrod palczastych, a szerokość głównej wiązki może być sterowana poprzez dtugość elektrod. W artykule przedstawione zostały opracowane przez autorów narzędzia do komputerowego wspomagani projektowania i symulacji działania przetworników IDT oraz ich weryfikacja eksperymentalna. Opracowane narzędzia symulacyjne, oparte na częstotliwościowo zależnej funkcji przejścia, jest bardzo wydajne obliczeniowo i pozwala na szybką identyfikację właściwości.

Słowa kluczowe: fale Lamba, ultradźwięki, symulacje, wykrywanie uszkodzeń, monitorowanie stanu konstrukcji, SHM

\section{INTRODUCTION}

The structural health monitoring (SHM) of plate-like structures is a recent topic of research, since many such constructions must meet high safety standards. Lamb waves (LWs) are a promising tool for these applications, thanks to their ability to propagate over long distances and sensitivity to various types of damages. A critical factor for the SHM of plate-like structures is the design of transducers and their distribution over the plate being investigated. A well-known approach in this field is the use of PZT transducers distributed over the structure. In these applications it is assumed that the emitters and sensors are omni-directional and, therefore, in order to perform damage localization, the processing of signals captured by a number of sensors is required.

Another approach, which can be used in this field, is the application of interdigital transducers (IDTs) for the generation and reception of Lamb waves (Raghavan and Cesnik 2007). Contrary to other types of ultrasonic transducers, comb-like electrodes used in the IDT make it possible to

\footnotetext{
* AGH University of Science and Technology, Faculty of Mechanical Engineering and Robotics, Department of Robotics and Mechatronics, Krakow, Poland; mmanka@agh.edu.pl
} 
excite a single-mode Lamb wave in the direction along the axis of the transducer. The feasibility of the IDTs for the generation of LWs in applications to structure monitoring was investigated by Monkhouse et al (Monkhouse et al. 2000; Monkhouse, Wilcox and Cawley 1997).

Numerical simulations are usually the first step of the testing of the performance of the designed transducers. In most cases numerical models are built in finite element analysis (FEA) software that allows for multiphysics simulation (i.e: Ansys Multiphysics). The simulations performed in the FEA environment are very accurate (Mańka et al. 2012), but the hardware requirements make the process very expensive and time-consuming. In order to speed up the computations another hybrid technique was reported recently (Paćko et al. 2012). The method assumes that the transducer is created as a FE model and wave generation process is simulated in the FEA software, whereas the simulations of the wave propagation in the tested structure is performed using a finite-difference method based on the LISA software and performed on GPU's using NVIDIA CUDA technology (Paćko et al. 2012). Although in this case the time required for simulations is reduced several times compared to the calculations with a similar accuracy performed by FEA alone, the time required to carry out numerous analyses to test multiple parameters of an IDT is still significant. Therefore, in this paper another method, based on the structure transfer function (STF) for the numerical simulation of the Lamb wave propagation and IDT testing is presented.

The paper is organized as follows: first a brief introduction to principles of wave generation using IDTs is presented, next a background of the numerical method based on the STF is given. An example of IDT design using the proposed technique is given next, followed by an experimental validation of the proposed method. In the final section conclusions are drawn.

\section{INTERDIGITAL TRANSDUCERS}

In many ultrasonic imaging applications broadband signals are desired to obtain a good time-domain localization of damage-reflected echoes. However, in the case of LWs, due to the dispersive nature, different frequency components travel with different velocities and hence the broadband signals have a considerable duration. Moreover, higher unwanted wave modes can be excited. Therefore, in these applications narrowband signals, chosen to operate at selected points of the dispersion characteristics, are commonly used.

Interdigital transducers are examples of transducers which can be designed to excite or sense modes with a specific wavelength. A typical IDT, shown in figure 1, consists of three layers: the bottom and top electrodes separated by a piezoelectric layer.

The top layer finger electrodes are the most significant feature of the IDT and the distance between the 'fingers' defines the dominant wavelength of the wave generated by the transducer (Monkhouse et al. 2000; Monkhouse, Wilcox and Cawley 1997). The piezoelectric layer may be made either of piezoelectric polymer, i.e.: PVDF (Capineri et al. 2002; Wilcox, Cawley and Lowe 1998), piezoceramic (Luginbuhl et al. 1997) or piezoceramic composite (Williams et al. 2002; Hayward et al. 2001). The type of the piezoelectric material determines the features of the transducers, for instance: elasticity, maximal energy and the frequency range of the generated waves.

Two main types of the IDT transducers can be distinguished depending on the electrode pattern, the traditional single-sided (IDT-SS) and the double-sided (IDT-DS) (Jin, Quek and Wang 2005).

A single-sided IDT, presented in figure 1, has comb-shape electrodes only on one side of the piezoelectric layer, while the second side is covered by the ground plate electrode. In this case three wires are required to connect electrical signals to the electrodes (two opposite phases and ground).

The double-sided IDT, shown in figure 2, has both sides covered by the interdigital electrodes. This design requires only two wires and does not need antisymmetric signal sources. Moreover, the amplitude of the GWs generated by IDT-DS can be higher than that generated by IDT-SS (Jin, Quek and Wang 2005).

Both types of the IDTs generate bi-directional waves (Na, Blackshire and Kuhra 2008; Na and Blackshire 2010) with the propagation direction perpendicular to the finger electrodes, and the divergence angle (the main lobe width) depends on the length of the fingers. a)

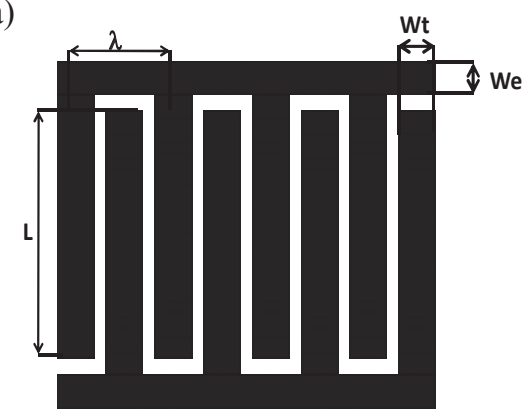

b)

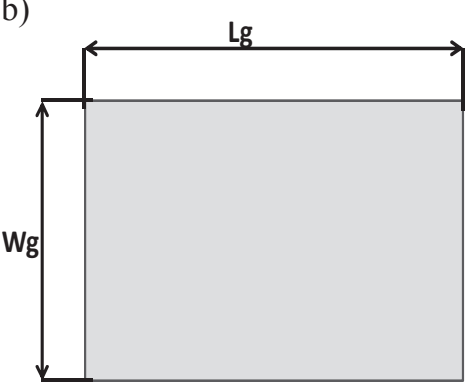

b)

$\mathbf{V +}$

V+ V-
Piezoelectric Layer GND

Fig. 1. Structure of a single-sided IDT transducer: (a) top electrode, (b) bottom electrode, (c) cross-section 
a)

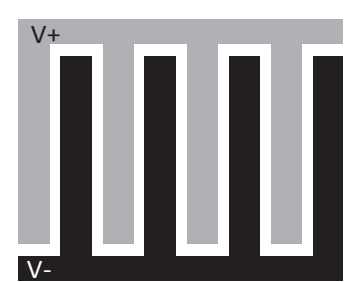

b)

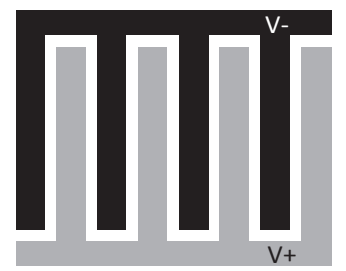

c)

Fig. 2. Electrode layout in the double-sided IDT: (a) top electrode, (b) bottom electrode, and (c) cross-section

\section{DESIGN OF THE IDT}

Lamb wave modes are generally dispersive, which means that the energy of different frequency components propagates at different speeds. To reduce the energy spreading it is possible to select points on the dispersion curves with an approximately constant group velocity. These points, referred to by (Wilcox 1998) as low-dispersivity points, can be localized on the dispersion curves as the maximum peak of the group velocity for a given mode. Examples of these points in the frequency-group velocity representation can be seen in figure 3.
Based on the dispersion characteristics, the wavelength of the corresponding Lamb wave can be calculated according to the equation

$$
\lambda=\frac{C_{p}}{f}
$$

where $C_{p}$ is the phase velocity and $f$ is the frequency. The frequency-wavelength representation of dispersion characteristics is shown in figure 4. From the figure, it can be seen that the curves intersect an exemplary line of constant wavelength of $7.5 \mathrm{~mm}$ at several frequencies. Therefore, in order to excite only the desired wave-mode, an appropriate bandwidth of the excitation signal has to be selected.

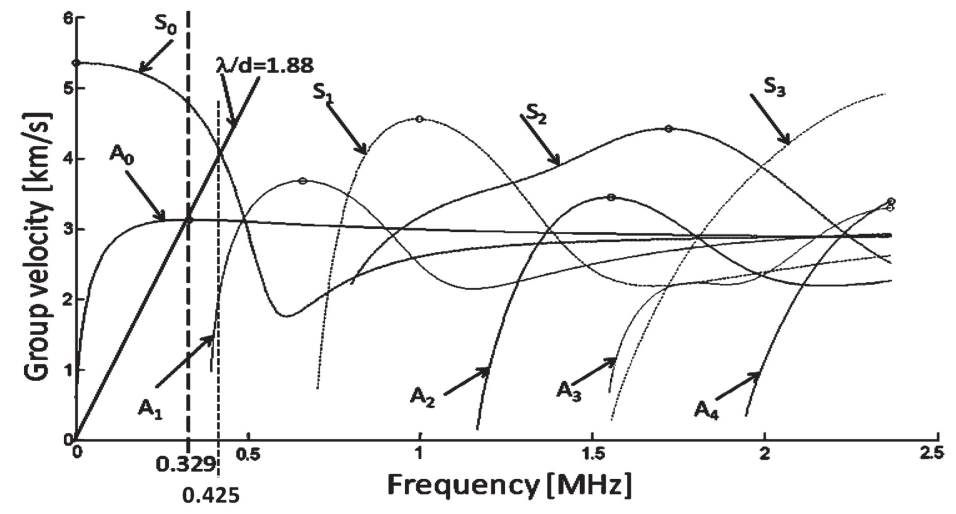

Fig. 3. Group velocity for a $4 \mathrm{~mm}$ aluminum plate

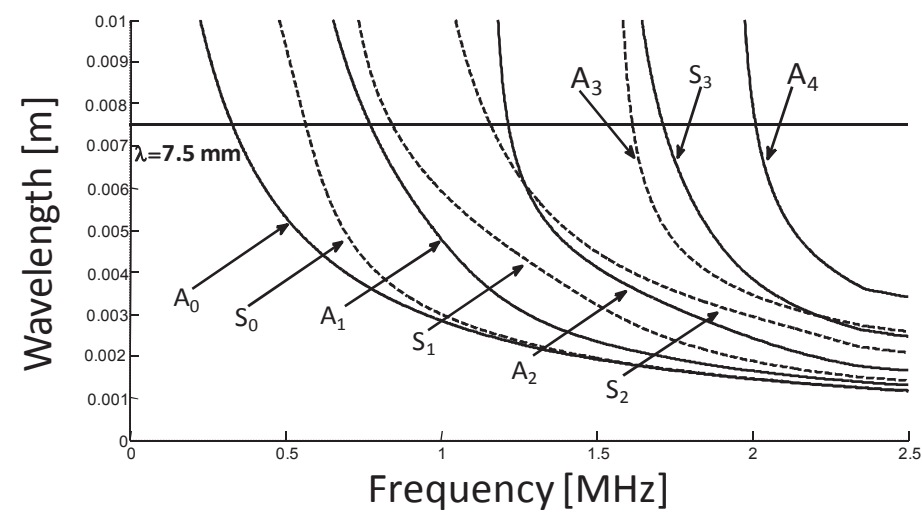

Fig. 4. Wavelength for a $4 \mathrm{~mm}$ aluminum plate 


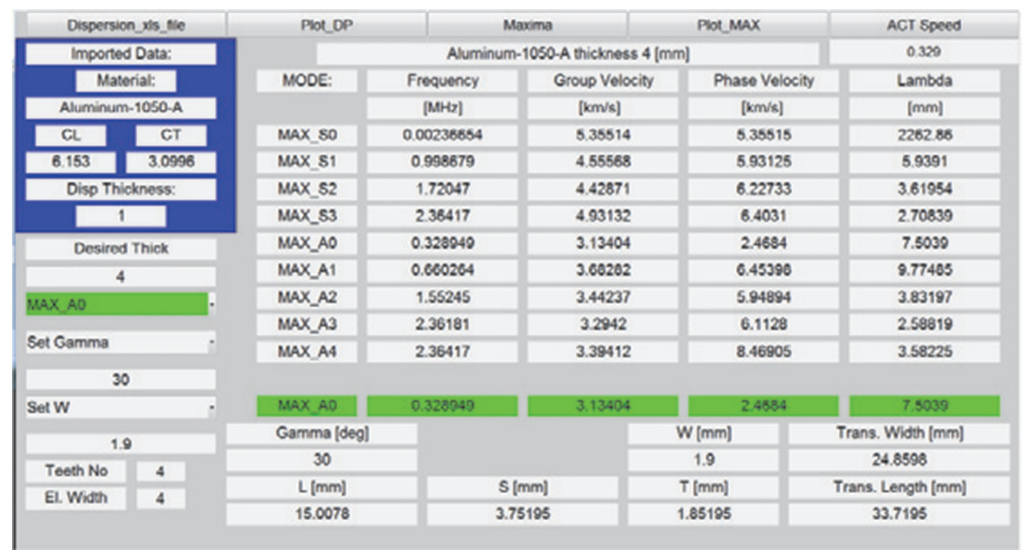

Fig. 5. Screen from CAD-IDT tool

a)

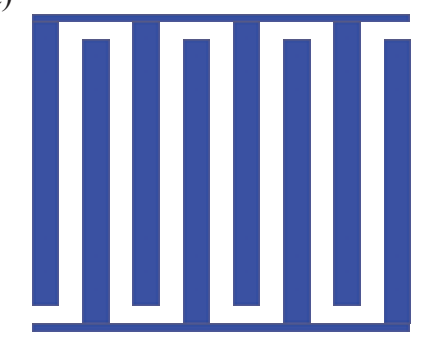

b)

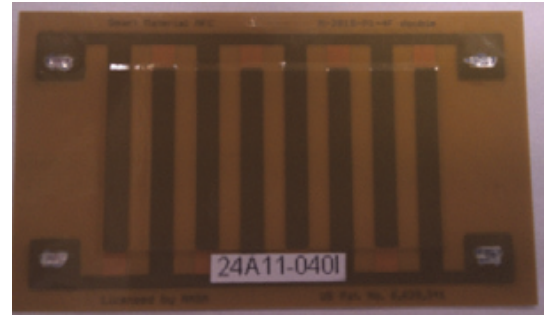

Fig. 6. The IDT designed in the CAD-IDT: (a) layout of electrodes and (b) manufactured prototype

Another aspect of the designing of IDT transducers is the directivity of the generating/sensing wave. It is connected with the length of the fingers and can be approximately written as:

$$
\gamma=\arcsin \left(\frac{\lambda}{L}\right)
$$

where $\gamma$ is the beam divergence angle.

In order to simplify the design process of the IDT a numerical tool was developed and implemented in the Matlab environment.

The tool developed for the computer aided design (CAD) of IDT (further referred as CAD-IDT), is presented in figure 5. The software is based on the dispersion curves calculated by solving the Rayleigh-Lamb equations (Rose 2004), next, it finds the maxima of the group velocities. Subsequently, for each mode the corresponding wavelength is calculated. Finally, for the selected mode and divergence angle, the main dimensions of the IDT are calculated. A visualization created in the CAD-IDT tool and a photograph of the manufactured transducer are presented in figure 6 .

\section{NUMERICAL SIMULATIONS}

In this section the background of a numerical technique based on the STF is given, followed by a description of the implementation of the technique.

\subsection{Development of the theoretical model}

In the proposed method the structure of the IDT is modelled as a set of point sources, the positions of which correspond to the shape of the electrodes of the transducer.

Based on the work of Wilcox (Wilcox 1998) and our own research, considered to lie beyond the scope of this paper, each of the electrodes has been modelled as a single line of the omni-directional point sources, and has been discretized with a step equal to 4 point sources per wavelength (fig. 7).

Each of these point sources generate a wave that propagates through the structure. The response of the surface $V_{r}(t, x)$ on dispersive Lamb waves, excited by signal $V_{e}(t)$ may be calculate using the following relation:

$$
V_{r}(t, x)=F^{-1}\left(V_{e}(\omega) \bullet G(k, \omega, x)\right)
$$

where $G(k, \omega, x)$ is the frequency dependent structure transfer function (STF), $k$ is the wavenumber of the propagating mode and $F^{-1}$ stands for the inverse Fourier transform. In the case when multiple symmetric $(S)$ and antisymmetric $(A)$ modes are present, the function $G(k, \omega, x)$ takes the form:

$$
G(k, \omega, x)=\frac{1}{\sqrt{x}}\left(\sum_{j=1}^{n} S_{j}(\omega) e^{i k^{S_{j}} x}+\sum_{l=1}^{m} A_{l}(\omega) e^{i k^{A l} x}\right)
$$

where $x$ is the propagation distance, $k$ is the wavenumber of the propagating mode and $S_{j}$ and $A_{l}$ correspond to the amplitudes of the symmetrical and antisymmetrical modes received. The term $1 / \sqrt{x}$ describes the aplitude decrease of the 


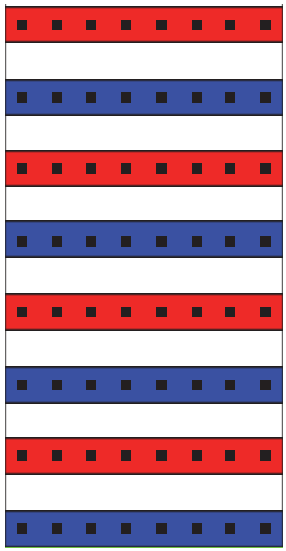

Fig. 7. Discretized IDT model

wave resulting from the geometrical (i.e. cylindrical) wavefront spreading (Rose 2004). The STF used is an approximate function that does not consider many phenomena observed during wave propagation in the structures (i.e.: material damping), but it may be used for the approximate modelling of the wave propagation (Giurgiutiu 2008). Since the transducer is modelled as a set of point sources, to calculate the overall wave field generated by the transducer, Huygens' principle was adapted. According to this principle (Wilcox 1998), the signal measured at a point is a linear superposition of the waves generated by the individual point sources according to Equation 3, and can be written as

$$
V_{I D T}(t)=\sum_{g=1}^{w} W^{g} P^{g} V_{r}^{g}(t)
$$

where $V_{I D T}(t)$ is the total response of the surface due to excitation $V_{e}(t)$ generated by the transducer, $V_{r}^{g}(t)$ is the response from a single source $g, P^{g}(t)$ takes the values -1 or 1 depending on the phase of excitation $(0, \pi)$, and $W^{g}$ is the weighting factor which aims to correct the amplitude separately in each electrode(i.e. when apodization is simulated).

\subsection{Matlab implementation of the proposed method}

The proposed method was implemented into the Matlab environment as a set of functions. The first step consists in defining the geometrical parameters of the IDT: length, width and number of electrodes and the length of the dominant wave. Next, the IDT's geometry is discretized into a set of point sources and the center of the transducer is calculated. The following step is the definition of the geometry of the structure being monitored and the measuring points and transducer positions. As the result of the geometries definitions, the matrix containing the distances from each of the point sources to each of the measuring points is created.

Two last steps of the proposed method are connected with the wave propagation calculations. First, the excitation signals are defined, (excitation frequency, number of cycles, sampling frequency and the type of modulation of the sine wave burst). Then, based on the excitation signal, the dispersion curves, the distance matrix and the time series for each pair of point source-measuring points are calculated. Finally, in the last step, the overall response at each measuring point, based on the calculated time series and power supply configuration (gain and phase for each of the finger electrodes), is obtained. The scheme of the implemented algorithm is presented in figure 8 .

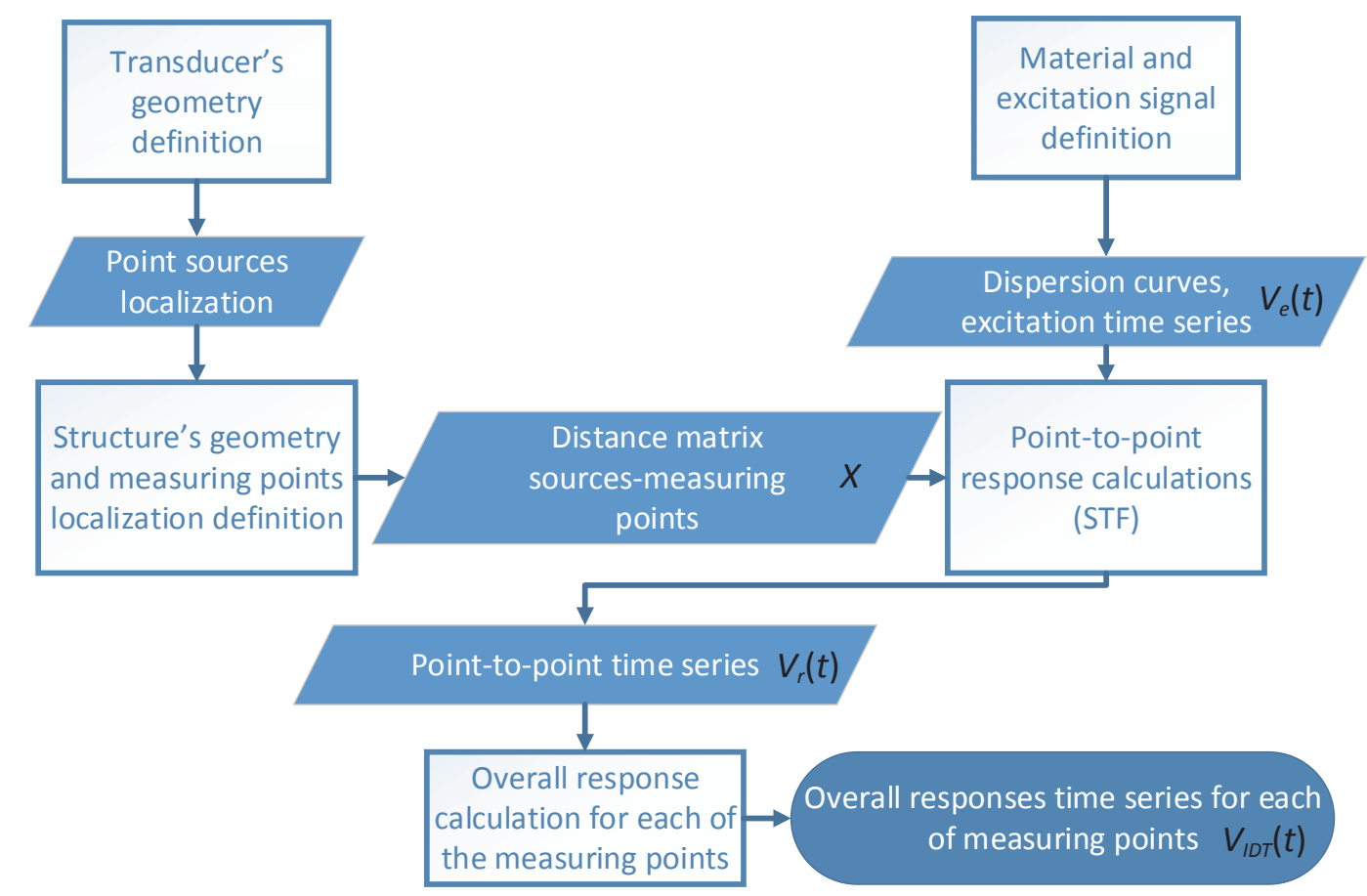

Fig. 8. Schematic representation of the algorithm workflow 


\section{EXPERIMENTAL VERIFICATION OF THE PROPOSED METHOD}

To verify the quality of the proposed method, the results obtained from the numerical model in Matlab were compared with experimental ones. The IDT used in the experiments was designed to excite the $\mathrm{A} 0$ mode in a $4 \mathrm{~mm}$ thick aluminum plate. According to the plots presented in the previous sections, this mode reaches its maximum group velocity at $\sim 330 \mathrm{kHz}$ and the corresponding wave length equals $7.5 \mathrm{~mm}$. Based on the values calculated in the developed CAE/CAD tool the dimensions of the designed transducer take the following values (tab. 1).

Table. 1

Electrode dimensions according to Figure 1

\begin{tabular}{|c|c|c|c|c|}
\hline$L[\mathrm{~mm}]$ & $L_{g}[\mathrm{~mm}]$ & $\lambda[\mathrm{mm}]$ & $W_{t}[\mathrm{~mm}]$ & $\begin{array}{c}\text { Number of } \\
\text { electrodes }\end{array}$ \\
\hline 15 & 28.5 & 7.5 & 1.9 & 8 \\
\hline
\end{tabular}

During the experimental tests the investigated transducers were mounted on a $1000 \times 1000 \times 4 \mathrm{~mm}$ aluminum plate using Loctite 3430 epoxy bond that was cured before the tests for at least $24 \mathrm{~h}$. The excitation signals were generated by a piezo-acquisition system specially designed for SHM applications, and the measurements of out-of-plane vibrations were performed using the Polytec PSV-400 scanning laser vibrometer located in front of the tested plate as shown in figure 9.

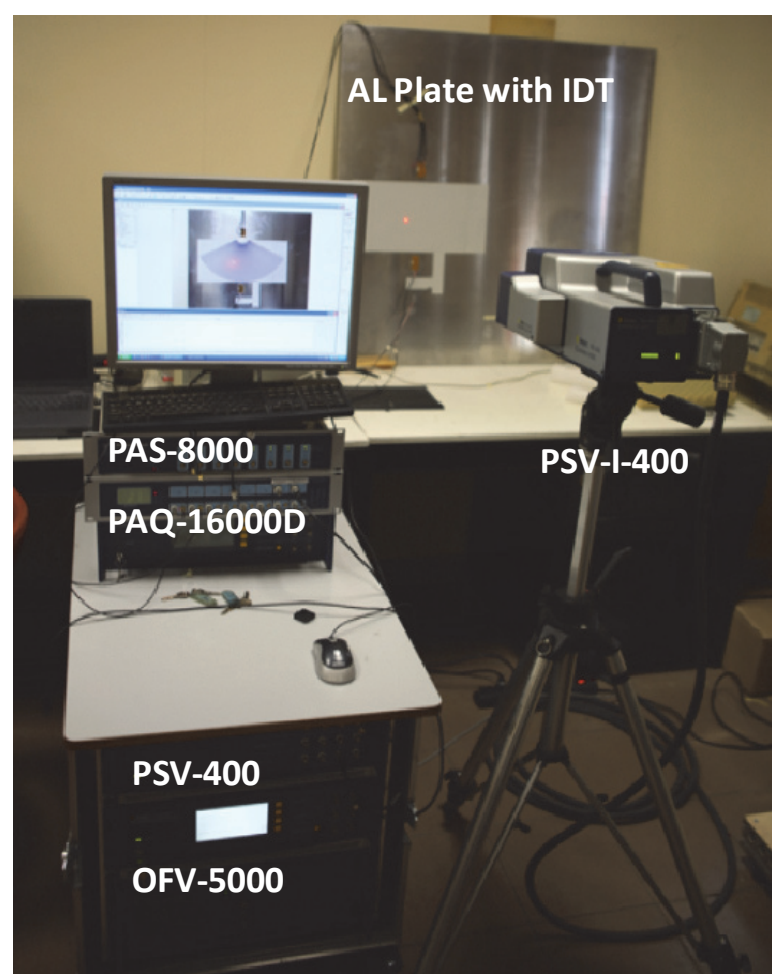

Fig. 9. Experimental set-up used to test the transducers
The excitation signals used in the numerical simulations and experiments consisted of a five-cycle tone sine burst modulated with a Hanning window. The burst frequencies used in the tests were 330 and $425 \mathrm{kHz}$. The frequency of 330 $\mathrm{kHz}$ is identified as the frequency with minimal dispersion for $\mathrm{A} 0$ mode in $4 \mathrm{~mm}$ thick aluminium. The other frequency is localized on the dispersive part of the characteristics and is out of the band of the transducer (Manka et al. 2011), but it was used to prove that the model may be used also if the dispersion level is significant. The measuring points in all cases were set on the radius of $150 \mathrm{~mm}$ from the center of the transducer (fig. 10).

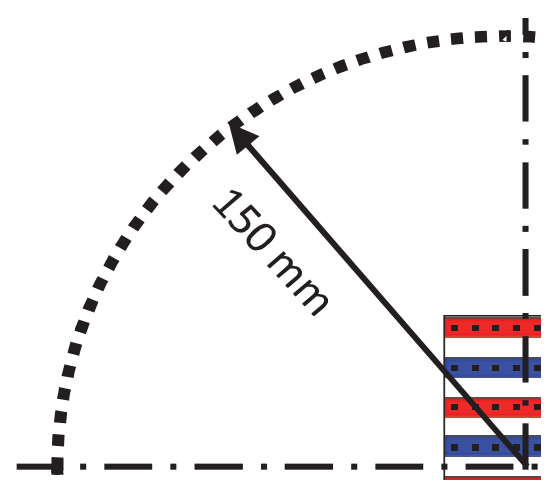

Fig. 10. Localization of the measurement points during simulations

To suppress the influence of noise, the measurements were repeated 4 times at each point and subsequently averaged and filtered with a bandpass filter with the bandwidth 100 $\mathrm{kHz}(+/-50 \mathrm{kHz}$ about the excitation frequency). The rest of the signal processing for numerical and experimental tests was similar. First the Hilbert transform was used to determine the envelopes of the time-history data for each of the measurement points. Then, the maximal value for each envelope was found and assumed to represent the generated amplitude. Finally, the calculated values were used to determine beam-patterns for each frequency. The comparison of the normalized time series obtained numerically and experimentally is presented in figure 11 .

From the figure, it is clearly visible that normalized time plots obtained from the numerical simulation are similar to the results measured during the experiments. The main difference is the amplitude at the beginning of the propagating wave $(45-52 \mu \mathrm{s})$. The small inconsistency between the signals can be explained by the simplifications resulting from the simulation technique.

In the second test a comparison of the generated beam-patterns obtained during numerical simulations and experimental tests was performed (figures 12-13).

Good agreement between experimental and numerical results can be observed at nominal frequency of $330 \mathrm{kHz}$. For a higher frequency, $425 \mathrm{kHz}$, some similarities can be also observed. The main source of the differences is the presence 


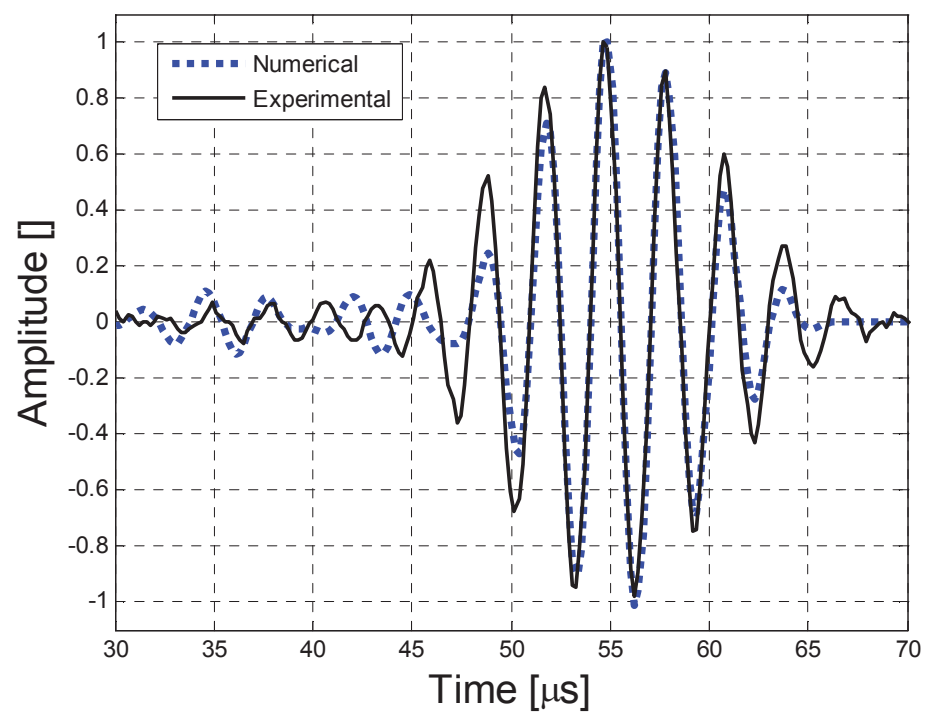

Fig. 11. Example of the snapshot of the vertical velocity

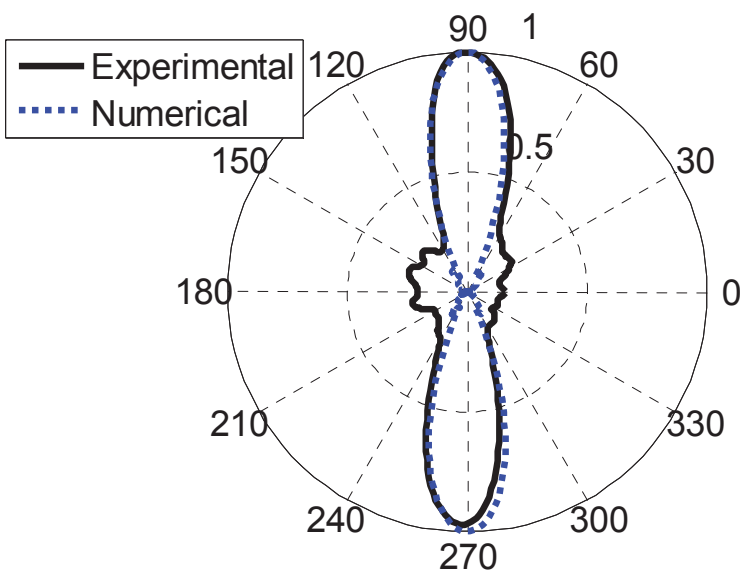

Fig. 12. Normalized beam patterns at the excitation frequency $330 \mathrm{kHz}$

of the dispersion in the generated waves and a lack of the A1 mode in the model, but this needs to be investigated further in our future research.

\section{CONCLUSIONS}

The results presented in the paper show that the proposed method may be used for the development of IDTs and simulations of Lamb wave propagation. The method is computationally efficient and it can be used for initial simulations to determine the properties of transducers and identify interesting frequencies or configurations for simulations using the finite element method or for experimental verification.

The main drawback of the proposed method, at the present stage, is a lack of direct relationships between the transducer material properties (i.e.: piezoelectric effect, stiffness of the material, bond quality etc.) and the produced excitation. In

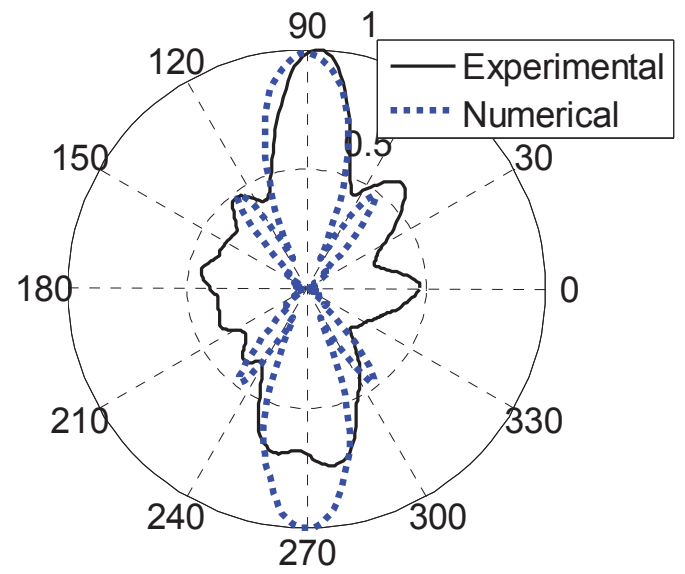

Fig. 13. Normalized beam patterns at the excitation frequency $425 \mathrm{kHz}$

the future extensions of the model additional features, such as, mode excitability and material properties of the transducer will be added to the model to increase its usefulness and accuracy.

The work was supported by the Polish Grant no.: N N503 159240: Technology of the ultrasonic micro-transducers in Lamb waves based SHM.

\section{References}

Capineri L., Gallai A., Masotti L., Materassi M. 2002, Design Criteria And Manufacturing Technology Of Piezo-Polymer Transducer Arrays For Acoustic Guided Waves Detection. IEEE Ultrasonic Symposium.

Giurgiutiu V. 2008, Structural health monitoring with piezoelectric wafer active sensors. Academic Press.

Hayward G., Hailu B., Farlow R., Gachagan A., McNab A. 2001, The design of embedded transducers for structural health monitoring applications. Proceedings of the SPIE, 2001, pp. 312-323.

Jin J., Quek S.T., Wang Q. 2005, Design of interdigital transducers for crack detection in plates. Ultrasonics, no. 43, pp. 481-493. 
Luginbuhl P., Collins S.D., Racine G., Gretillat M.A., de Rooij N.F., Brooks K.G., Setter N. 1997, Microfabricated Lamb Wave Device Based on PZT Sol-Gel Thin Film for Mechanical Transport of Solid Particles and Liquids. Journal of Microelectromechanical Systems, vol 6, no. 4, pp. 337-346.

Mańka M., Rosiek M., Martowicz A., Stępiński T., Uhl T. 2012, Lamb wave transducers made of piezoelectric macro-fiber composite, Structural Control and Health Monitoring, 2012.

Manka M.M., Rosiek M., Martowicz A., Uhl T., Stepinski T. 2011, Properties of Interdigital Transducers for Lamb-wave Based SHM Systems. The 8th International Workshop on Structural Health Monitoring Stanford University - 2011, Stanford.

Monkhouse R.S.C., Wilcox P.D., Cawley P. 1997, Flexible interdigital PVDF transducers for the generation of Lamb waves in structures. Ultrasonics, no. 35, pp. 489-498.

Monkhouse R.S.C., Wilcox P.W., Lowe M.J.S., Dalton R.P., Cawley P. 2000, The rapid monitoring of structures using interdigital Lamb, Smart Materials and Structures, no. 9, pp. 304-309.

Na J.K., Blackshire J.L. 2010, Interaction of Rayleigh surface waves with a tightly closed fatigue crack, NDT\&E International, 2010, pp. 432-439.
Na J.K., Blackshire J.L., Kuhra S. 2008, Design, fabrication and characterization of single-element interdigital transducers for NDT applications. Sensors and Actuators A, no. 148, pp. 359-365.

Paćko P., Bielak T., Spwncer B., Staszewski J., Uhl T. 2012, Lamb wave propagation modelling and simulation using parallel processing architecture and graphical cards. Smart Materials and Structures, 2012, pp. 1-13.

Raghavan A., Cesnik C.E.S. 2007, Review of Guided-wave Structural Health Monitoring. The shock and vibration digest, vol 2, no. 39, pp. 91114.

Rose J. 2004, Ultrasonic waves in solid media. Cambridge University Press. Wilcox P.D. 1998, Lamb Wave Inspection of Large Structures Using Permanently Attached Transducers. Imperial College of Science, Technology and Medicine, London.

Wilcox P.D., Cawley P., Lowe M.J.S. 1998, Acoustic fields from PVDF interdigital transducers. IEE Proceedings Science, Measurement and Technology, 1998, pp. 250-259.

Williams B.R., Park G., Inman D.J., Wilkie K.W. 2002, An Overview of Composite Actuators with Piezoceramic Fibers. 20th International Modal Analysis Conference, Los Angeles. 